\title{
MODEL SISTEM PENUNJANG KEPUTUSAN UNTUK MENENTUKAN PERPANJANGAN KONTRAK KERJA MOTIVATOR MENGGUNAKAN METODE SAW PADA YAYASAN PENGEMBANGAN ANAK INDONESIA BIMBA AIUEO
}

\author{
Rizki Sanjaya ${ }^{1}$, Agus Umar Hamdani2* ${ }^{2 *}$ \\ ${ }^{1,2}$ Fakultas Teknologi Informasi, Sistem Informasi, Universitas Budi Luhur, Jakarta, Indonesia \\ Email: ${ }_{1}^{1} 1612520062 @$ student.budiluhur.ac.id, $2{ }^{2 *}$ agus.umarhamdani@ budiluhur.ac.id
}

\begin{abstract}
Abstrak - Yayasan Pengembangan Anak Indonesia biMBA-AIUEO adalah sebuah lembaga swasta yang bergerak di pendidikan anak usia balita. Diadakan seleksi penerimaan calon motivator untuk membantu kegiatan belajar mengajar setiap tahun. Setiap calon motivator akan mengikuti tes evaluasi kompetensi dasar motivator (EKODAM). Saat ini, pengolahan data penilaian motivator sudah terkomputerisi, namun hanya menggunakan aplikasi Excel dan belum menggunakan formula otomatis yang ada di dalam aplikasi tersebut, serta tenaga administrasi yang belum familier dengan penggunaan teknologi informasi sehingga menyebabkan pengolahan data penilaian motivator membutuhkan waktu yang lama. Merujuk pada kondisi bisnis diatas, maka peneliti mengusulkan untuk membangun sebuah sistem informasi untuk menentukan perpanjangan kontrak kerja motivator. Metode yang digunakan untuk mengolah data menggunakan Simple Additive Weighting (SAW). Metode tersebut digunakan karena nilai bobot untuk setiap kriteria penilaian sudah diketahui. Metode pengumpulan data menggunakan wawancara, pengamatan langsung dan angket kuesioner. Implementasi sistem pengambilan keputusan menggunakan Visual Studio 2008 dengan database MySQL. Tujuan penelitian ini adalah membangun prototipe sistem penunjang keputusan yang memberikan rekomendasi perpanjangan kontrak kerja motivator berdasarkan hasil penilaian evaluasi kompetensi dasar motivator.
\end{abstract}

Kata Kunci: Sistem Penunjang Keputusan, Simple Additive Weighting, Perpanjangan Kontrak Kerja Motivator

\begin{abstract}
The biMBA-AIUEO Indonesian Child Development Foundation is a private institution engaged in the education of children under five. Selection of prospective motivator candidates to assist teaching and learning activities is carried out every year. Each motivator candidate will take the motivator basic competency evaluation test (EKODAM). Currently, the processing of assessment data has been computerized, but only uses the Excel application and has not used the automatic formulas, and administrative staff who are not familiar with information technology, so that processing of motivator assessment take a long time. Referring to the business conditions above, the researcher proposes to build an information system to determine the extension of the motivator work contract. The method used to process the data using the Simple Additive Weighting (SAW). This method is used because the weight value for each assessment criterion is known. Methods of collecting data using interviews, direct observation and questionnaires. Implementation of the decision-making system using Visual Studio 2008 with MySQL database. The purpose of this research is built a prototype of a decision support system that provides recommendations for extending a motivator's employment contract based on the results of the evaluation of the basic competence of motivators.
\end{abstract}

Keywords: Decision Support System, Simple Additive Weighting, The Motivator's Work Contract Extension

\section{PENDAHULUAN}

Sistem pendukung keputusan merupakan suatu aplikasi interaktif yang digunakan para manager untuk mengambil keputusan semistruktur dan terstruktur [1]. Yayasan Pengembangan Anak Indonesia biMBA-AIUEO merupakan sebuah lembaga pendidikan untuk anak-anak dengan usia dibawah lima tahun. Setiap tahun diadakan penerimaan calon tenaga didik baru untuk membantu kegiatan belajar mengajar. Yayasan Pengembangan Anak Indonesia biMBA AIUEO memiliki metode tersendiri dalam menentukan perpanjangan kontrak kerja motivator yang dinyatakan lulus dalam tes evaluasi kompetensi dasar motivator (EKODAM). Saat ini, pengolahan data EKODAM sudah terkomputerisi, namun hanya menggunakan aplikasi Excel dan belum menggunakan rumus-rumus bisnis / formula otomatis yang ada di dalam aplikasi tersebut sehingga menyebabkan pengolahan data penilaian motivator membutuhkan waktu yang lama. Selain itu, tenaga administrasi yang belum familier dengan penggunaan teknologi informasi juga menjadi penyebab pengolahan data EKODAM menjadi lama. Merujuk pada kondisi bisnis diatas, maka penelitian bertujuan untuk menganalisis dan membangun sistem penunjang keputusan pemilihan motivator untuk perpanjangan kontrak kerjanya di Yayasan Pengembangan Anak Indonesia biMBA AIUEO. Dengan adanya sistem penilaian motivator tersebut, diharapkan pihak Yayasan dapat mengetahui kualitas motivator yang mengajar diharapkan dapat meningkatkan kualitas peserta didik. Peneliti menggunakan metode SAW (Simple Additive Weighting) untuk mengolah data nilai akhir setiap kriteria penilaian motivator. Alasan peneliti menggunakan metode tersebut dikarenakan nilai bobot EKODAM untuk setiap kriteria sudah diketahui berdasarkan hasil wawancara dengan pihak manajemen selain itu, sumber referensi terkait metode yang diambil berasal dari : penelitian pertama [2] yang membahas tentang model sistem informasi untuk menentukan promosi kenaikan karyawan, kemudian penelitian kedua [3] yang membahas model sistem informasi untuk menentukan pemilihan Rizky Sanjaya | http://jom.fti.budiluhur.ac.id/index.php/IDEALIS/index | Page 167 
karyawan baru, dan penelitian ketiga [4] membahas sistem untuk menentukan penilaian kinerja karyawan dan penelitian keempat [5] yang membahas sistem informasi yang digunakan untuk penilaian guru terbaik.

\section{METODE PENELITIAN}

Metode analisis data dalam penelitian ini menggunakan metode Simple Additive Weighting (SAW) dan sering dikenal dengan istilah metode penjumlahan terbobot. Konsep dasar metode SAW adalah mencari penjumlahan terbobot dari rating kinerja pada setiap alternatif pada semua atribut [6]. Metode SAW membutuhkan proses normalisasi matriks keputusan (X) ke suatu skala yang dapat diperbandingkan dengan semua rating alternatif yang ada. Langkah-langkah perhitungan nilai menggunakan metode SAW [7] :

3.1. Menentukan kriteria-kriteria yang akan dijadikan acuan dalam pengambilan keputusan, yaitu $\mathrm{Ci}$.

3.2. Menentukan rating kecocokan setiap alternatif pada setiap kriteria.

3.3. Membuat matriks keputusan berdasarkan kriteria (Ci), kemudian melakukan normalisasi matriks berdasarkan persamaan yang disesuaikan dengan jenis atribut Benefit atau Cost sehingga diperoleh matriks ternormalisasi R menggunakan persamaan 1 .

$$
\begin{array}{ll}
r_{i j} \frac{x_{i j}}{\operatorname{Max}\left(x_{i j}\right)} & \text { Jika j adalah atribut keuntungan (benefit) } \\
r_{i j} \frac{\operatorname{Min}\left(x_{i j}\right)}{x_{i j}} & \text { Jika j adalah atribut biaya (cost) }
\end{array}
$$$$
\text { (persamaan 1) }
$$

Dimana :
rij $\quad=$ nilai rating kinerja ternormalisasi
xij $\quad=$ nilai atribut yang dimiliki dari setiap kriteria
Benefit $\quad=$ jika nilai terbesar adalah terbaik
Cost $\quad$ jika nilai terkecil adalah terbaik dimana rij adalah rating kinerja ternormalisasi dari alternatif Ai pada atribut $\mathrm{Cj} ; \mathrm{i}=1,2, \ldots \ldots . ., \mathrm{n}$.

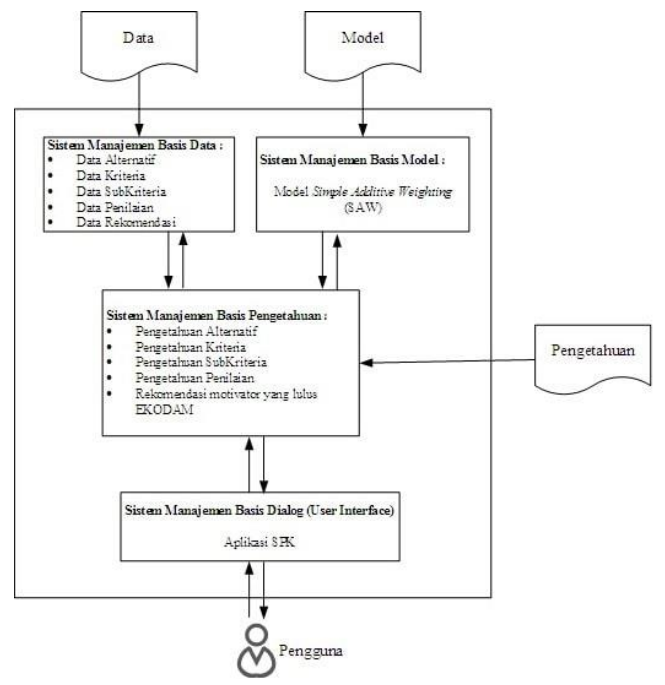

Gambar 1. Komponen Decision Support System

Pada gambar 1 dijelaskan model komponen sistem penunjang keputusan [8] terdiri atas : Sistem Manajemen Basis Data berisi model untuk merekam data yang berkaitan dengan pengambilan keputusan, diantaranya : data alternatif, data kriteria, data subkriteria, data penilaian dan data rekomendasi. Sistem Manajemen Manajemen Basis Model berisi model untuk mengolah data penilaian menggunakan metode Simple Additive Weighting (SAW). Sistem Manajemen Bisnis Pengetahuan berisi informasi / pengetahuan yang dapat menjadi rekomendasi bagi user. 


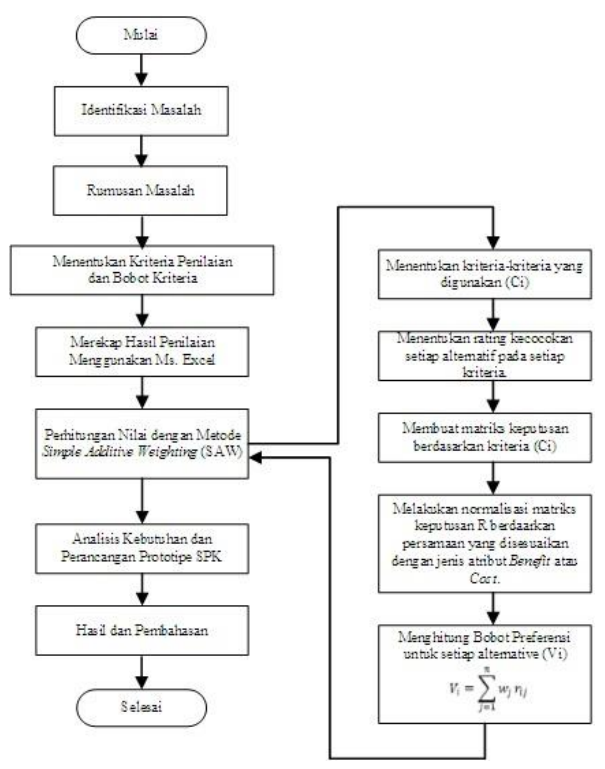

Gambar 2. Langkah-langkah Penelitian

Metodologi penelitian [8] merupakan urutan instruksi yang digunakan untuk analisis data yang disajikan secara sistematik. Berikut ini adalah desain penelitian untuk memberikan solusi dalam penentuan motivator dapat dilihat pada gambar 2. Gambar 2 merupakan metodologi penelitian yang dilakukan dalam penelitian ini. Tahap 1 : Mendefinisikan masalah pada saat menentukan motivator yang lulus dalam evaluasi kompetensi dasar motivator. Tahap 2 : Melakukan identifikasi solusi masalah berdasarkan teori dan literatur study. Tahap 3 : Mendefinisikan kriteria dan bobot untuk setiap kriteria penilaian. Tahap 4 : Melakukan olah data penilaian motivator dengan Microsoft Excel. Tahap 5 : Mengolah data menggunakan metode Simple Additive Weighting (SAW). Tahap 6 : Melakukan analisa terhadap masalah mnggunakan pendekatan Fishbone Diagram, kemudian dilanjutkan dengan mengidentifikasi kebutuhan sistem usulan, merancang sistem menggunakan pendekatan Object-Oriented Analysis and Design (OOAD) serta mengimplementasikan model sistem menggunakan bahasa pemrograman Visual Basic 2008 dengan DBMS MySQL. Tahap 7 : Pembahasan dari pengujian sistem dan menarik kesimpulan hasil penelitian.

\section{HASIL DAN PEMBAHASAN}

\subsection{Analisa Proses Bisnis}

Gambar 3 merupakan proses penilaian motivator, dimana Direktur Operasional mengisi nilai evaluasi dasar motivator untuk setiap motivator setiap tahun di form penilaian motivator. Kemudian menentukan status kelulusan untuk setiap kriteria penilaian.

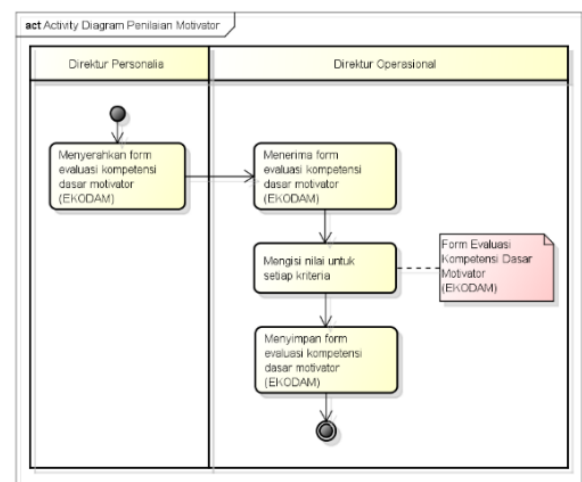

Gambar 3. Activity Diagram Penilaian Motivator

Gambar 4 merupakan proses bisnis rekomendsi perpanjangan kontrak kerja motivator, dimana Direktur Operasional menyerahkan data rekomendasi perpanjangan kontrak kerja motivator kepada direktur personalia. 
Halaman 167- 176

available online at $\mathrm{http} / / /$ jom.fti.budiluhur.ac.id/index.php/IDEALIS/index

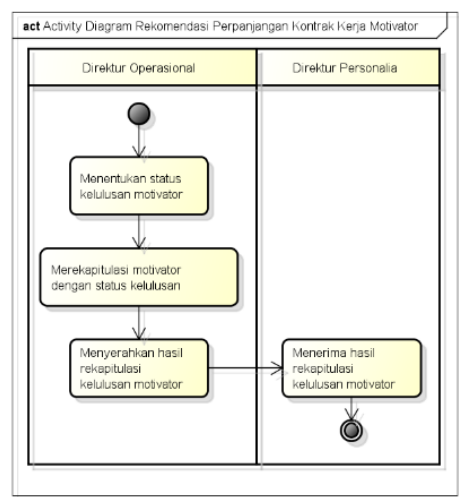

Gambar 4. Activity Diagram Rekomendasi Perpanjangan Kontrak Kerja Motivator

\subsection{Analisa Masalah}

Dalam menganalisa masalah terkait pengambilan keputusan perpanjangan kontrak kerja motivator pada Yayasan Pengembangan Anak Indonesia biMBA AIUEO, maka penulis menggunakan pendekatan Fishbone Diagram. Fishbone Diagram merupakan alat bantu analisis masalah untuk mengetahui keterhuhungan antara sebab dan akibat [9]. Hasil analisa masalah tersebut dapat dilihat pada gambar 5.

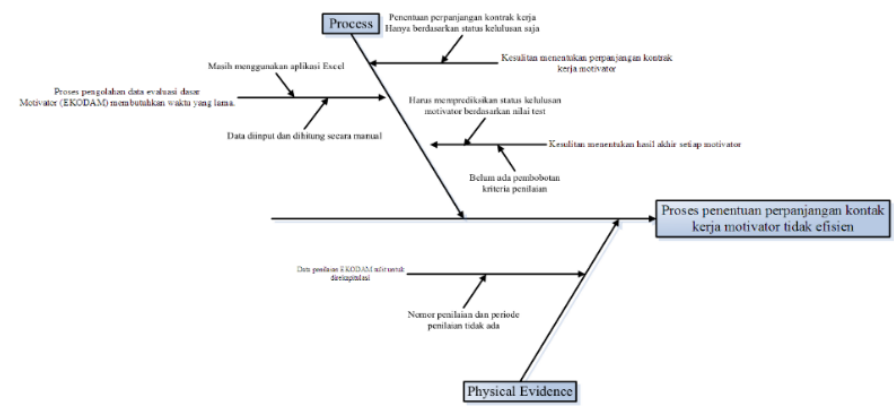

Gambar 5. Hasil Analisa Masalah dengan Fishbone Diagram

Kategori Process, terdapat 3 (tiga) masalah utama yaitu : proses pengolahan data EKODAM yang membutuhkan waktu yang lama, kesulitan menentukan perpanjangan kontrak kerja motivator dan kesulitan untuk menentukan hasil akhir motivator. Kategori Physical Evidence, terdapat 1 (satu) masalah utama, yaitu : data penilaian saat ini sulit untuk direkapitulasi. Adapun solusi bisnis SI/TI dapat dilihat pada tabel 1.

Tabel 1. Identifikasi Solusi Bisnis SI/TI

\begin{tabular}{|l|l|l|}
\hline \multicolumn{1}{|c|}{ Masalah } & \multicolumn{1}{|c|}{ Penyebab } & \multicolumn{1}{c|}{ Solusi Bisnis SI / TI } \\
\hline $\begin{array}{l}\text { - Proses pengolahan data evaluasi } \\
\text { kompetensi dasar monitor } \\
\text { (EKODAM) membutuhkan } \\
\text { waktu yang lama. }\end{array}$ & $\begin{array}{l}\text { - Diinput secara manual di aplikasi Ms. } \\
\text { Excel dan data dihitung secara } \\
\text { manual. }\end{array}$ & $\begin{array}{l}\text { - Sistem harus bisa mengolah data } \\
\text { penilaian motivator dengan secara } \\
\text { otomatis. }\end{array}$ \\
\hline $\begin{array}{l}\text { Kesulitan dalam menentukan } \\
\text { status kelulusan setiap } \\
\text { motivator. }\end{array}$ & $\begin{array}{l}\text { - Harus memprediksikan status } \\
\text { kelulusan motivator berdasarkan nilai } \\
\text { test dan belum ada pembobotan } \\
\text { kriteria penilaian. }\end{array}$ & $\begin{array}{l}\text { - Sistem harus bisa memberikan } \\
\text { informasi status kelulusan setiap } \\
\text { motivator secara otomatis. }\end{array}$ \\
\hline $\begin{array}{l}\text { Form penilaian evaluasi dasar } \\
\text { motivator (EKODAM) berisi } \\
\text { informasi yang tidak lengkap. }\end{array}$ & - Data tanggal penilaian tidak diisi. \\
\hline
\end{tabular}

\subsection{Analisa Data Menggunakan Metode Simple Additive Weighting}

Terdapat 5 (lima) alternatif yang akan dinilai yang diinisialkan, yaitu : M1 (Motivator ke-1), M2 (Motivator ke-2), M3 (Motivator ke-3), M4 (Motivator ke-4) dan M5 (Motivator ke-5). Model hirarki kriteria dan alternatif dapat dilihat pada gambar 6. 
Halaman 167- 176

available online at $\mathrm{http} / / /$ jom.fti.budiluhur.ac.id/index.php/IDEALIS/index

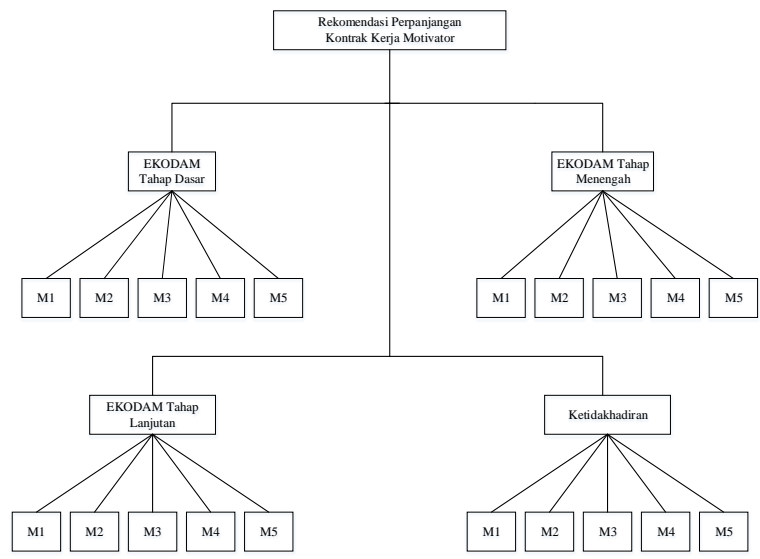

Gambar 6. Model Hirarki Kriteria dan Alternatif

Penjelasan mengenai gambar 6 dijelaskan sebagai berikut:

a. Identifikasi Tujuan (Goal)

Adapun tujuan (goal) dalam sistem penunjang keputusan ini adalah menentukan perpanjangan kontrak kerja motivator berdasarkan kriteria penilaian.

b. Identifikasi Kriteria

Berdasarkan wawancara yang dilakukan kepada Direktur Operasional BiMBA AIUEO sebagai pengambil keputusan, yang terdiri atas :

1) EKODAM Tahap Dasar diinisialkan dangan K1

EKODAM Tahap Dasar merupakan kriteria untuk menilai keberhasilan setiap motivator terhadap materi / kurikulum tingkat dasar.

2) EKODAM Tahap Menengah diinisialkan dangan K2

EKODAM Tahap Menengah merupakan kriteria untuk menilai keberhasilan setiap motivator terhadap materi / kurikulum tingkat menengah.

3) EKODAM Tahap Lanjutan diinisialkan dangan K3

EKODAM Tahap Lanjutan merupakan kriteria untuk menilai keberhasilan setiap motivator terhadap materi / kurikulum tingkat lanjutan.

4) EKODAM Ketidakhadiran diinisialkan dangan K4

Adapun penggolongan kriteria dan subkriteria penilaian dapat dilihat pada tabel 2 dan tabel 3 .

Tabel 2. Penggolongan Kriteria

\begin{tabular}{|c|l|c|l|}
\hline $\begin{array}{l}\text { Kode } \\
\text { Kriteria }\end{array}$ & Nama Kriteria & Bobot Kriteria & Tipe Kriteria \\
\hline K1 & EKODAM Tahap Dasar & $30 \%$ & Benefit \\
\hline K2 & EKODAM Tahap Menengah & $30 \%$ & Benefit \\
\hline K3 & EKODAM Tahap Lanjutan & $30 \%$ & Benefit \\
\hline K4 & Ketidakhadiran & $10 \%$ & Cost \\
\hline \multicolumn{2}{|c|}{ TOTAL } & $100 \%$ & \\
\hline
\end{tabular}

Tabel 3. Penggolongan Sub Kriteria

\begin{tabular}{|c|c|c|c|}
\hline $\begin{array}{l}\text { Kode } \\
\text { Kriteria }\end{array}$ & Nama Kriteria & $\begin{array}{l}\text { Kode } \\
\text { SubKriteria }\end{array}$ & Nama Subkriteria \\
\hline \multirow[t]{3}{*}{$\mathrm{K} 1$} & \multirow[t]{3}{*}{ EKODAM Tahap Dasar } & $\mathrm{K} 11$ & Tahap Dasar 1 \\
\hline & & K12 & Tahap Dasar 2 \\
\hline & & K13 & Tahap Dasar 3 \\
\hline \multirow[t]{3}{*}{$\mathrm{K} 2$} & \multirow[t]{3}{*}{ EKODAM Tahap Menengah } & $\mathrm{K} 21$ & Tahap Menengah 1 \\
\hline & & $\mathrm{K} 22$ & Tahap Menengah 2 \\
\hline & & $\mathrm{K} 23$ & Tahap Menengah 3 \\
\hline \multirow[t]{3}{*}{$\mathrm{K} 3$} & \multirow[t]{3}{*}{ EKODAM Tahap Lanjutan } & K31 & Tahap Lanjutan 1 \\
\hline & & K32 & Tahap Lanjutan 2 \\
\hline & & K33 & Tahap Lanjutan 3 \\
\hline $\mathrm{K} 4$ & Ketidakhadiran & K41 & Ketidakhadiran \\
\hline
\end{tabular}


Halaman 167- 176

available online at $\mathrm{http} / / /$ jom.fti.budiluhur.ac.id/index.php/IDEALIS/index

c. Identifikasi Alternatif

Data alternatif merupakan data motivator yang akan direkomendasi untuk menerima perpanjangan kontrak kerja. Hasil identifikasi alternatif dapat dilihat pada tabel 4.

Tabel 4. Identifikasi Alternatif

\begin{tabular}{|c|l|l|l|}
\hline Kode Motivator & Nama Motivator & Posisi & \multicolumn{1}{|c|}{ Unit } \\
\hline M1 & Maulinda & Motivator & Berdikari \\
\hline M2 & Indah Muwartini & Motivator & Gili Sampeng \\
\hline M3 & Marita Rachmawati & Motivator & Gambas \\
\hline M4 & Neneng Marlina & Motivator & Asem Baris \\
\hline M5 & Nani Subekti & Motivator & Tanggung Duren \\
\hline
\end{tabular}

\subsection{Pengolahan Data}

Hasil pengolahan data penilaian diubah ke dalam bentuk matriks keputusan berdasarkan criteria C, kemudian dilakukan normalisasi nilai menggunakan atribut Benefit dan Cost. Nilai kriteria dan subkriteria penilaian untuk setiap alternatif, serta hasil matriks keputusan ternormalisasi dapat dilihat pada tabel 5, tabel 6 dan tabel 7.

Tabel 5. Nilai Sub Kriteria Untuk Setiap Alternatif

\begin{tabular}{|c|l|l|l|l|l|l|l|l|l|l|l|l|l|}
\hline \multirow{2}{*}{$\begin{array}{l}\text { KANDIDAT } \\
\text { ALTERNATIF }\end{array}$} & \multicolumn{10}{|c|}{ KODE KRITERIA PENILAIAN DAN SUBKRITERIA } \\
\cline { 2 - 12 } & \multicolumn{1}{|c|}{ K1 (Tahap Dasar) } & \multicolumn{6}{|c|}{ K2 } \\
Menengah)
\end{tabular}

Tabel 6. Nilai Kriteria Per Alternatif

\begin{tabular}{|r|l|r|r|r|r|}
\hline \multicolumn{2}{|l|}{ KANDIDAT } & \multicolumn{5}{|c|}{ KODE KRITERIA } \\
\cline { 3 - 6 } \multicolumn{2}{|l|}{} & \multicolumn{1}{|l|}{ K1 } & \multicolumn{1}{l|}{ K2 } & \multicolumn{1}{l|}{ K3 } & \multicolumn{1}{l|}{ 44 } \\
\hline $\begin{array}{r}\text { Kode } \\
\text { Motivator }\end{array}$ & Nama Motivator & $\begin{array}{l}\text { Tahap } \\
\text { Dasar }\end{array}$ & $\begin{array}{l}\text { Tahap } \\
\text { Menengah }\end{array}$ & $\begin{array}{l}\text { Tahap } \\
\text { Lanjutan }\end{array}$ & Ketidakhadiran \\
\hline M1 & Maulinda & 79.33 & 80.00 & 81.67 & 0 \\
\hline M2 & Indah Muwartini & 79.00 & 80.00 & 82.33 & 0 \\
\hline M3 & $\begin{array}{l}\text { Marita } \\
\text { Rachmawati }\end{array}$ & 86.00 & 83.33 & 82.67 & 0 \\
\hline M4 & Neneng Marlina & 88.33 & 85.67 & 87.33 & 0 \\
\hline M5 & Nani Subekti & 86.67 & 80.67 & 79.67 & 2 \\
\hline
\end{tabular}

Tabel 7. Menghitung Matriks Keputusan Ternormalisasi

\begin{tabular}{|c|c|c|c|c|c|}
\hline \multicolumn{2}{|c|}{ KANDIDAT ALTERNATIF } & \multicolumn{4}{|c|}{ KODE KRITERIA } \\
\hline & & $\mathbf{K l}$ & K2 & $\mathrm{K} 3$ & $\mathbf{K 4}$ \\
\hline $\begin{array}{l}\text { Kode } \\
\text { Motivator }\end{array}$ & Nama Motivator & Tahap Dasar & Tahap Menengah & $\begin{array}{l}\text { Tahap } \\
\text { Lanjutan }\end{array}$ & Ketidalkhadiran \\
\hline M1 & Maulinda & 79.33 & 80.00 & 81.67 & 0 \\
\hline M2 & Indah Muwartini & 79.00 & 80.00 & 82.33 & 0 \\
\hline M3 & Marita Rachmawati & 86.00 & 83.33 & 82.67 & 0 \\
\hline M4 & Gitta Mayga Arismawan & 88.33 & 85.67 & 87.33 & 0 \\
\hline M5 & Nani Subekti & 86.67 & 80.67 & 79.67 & 2 \\
\hline \multicolumn{2}{|c|}{ NILAI MAX / MIN } & 88.33 & 85.67 & 87.33 & 0 \\
\hline \multicolumn{2}{|r|}{ Keterangan } & \multicolumn{3}{|c|}{ Benefit } & Cost \\
\hline
\end{tabular}

Perhitungan normalisasi matriks keputusan (R) setiap kriteria penilaian motivator diperoleh menggunakan persamaan 1 dan persamaan 2 .

Untuk menghitung normalisasi matriks keputusan R untuk atribut Benefit menggunakan persamaan 1.

.Persamaan 1 


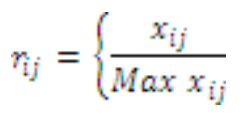

Untuk menghitung normalisasi matriks keputusan $\mathrm{R}$ untuk atribut Cost menggunakan persamaan 2.

$$
\mathrm{T}_{\mathrm{if}}=\left\{\frac{\operatorname{Min} x_{\mathrm{i} f}}{x_{i j}}\right.
$$

Berikut ini adalah contoh perhitungan Kriteria EKODAM Tahap Dasar (K1) menggunakan persamaan 1.

$$
R 11=\frac{79,33}{\operatorname{MAX}(79.33 ; 79.00 ; 86.00 ; 88.33 ; 87.67)}=\frac{79.33}{88.33}=0.898
$$

Berikut ini adalah contoh perhitungan Kriteria Ketidakhadiran (K4) menggunakan persamaan 2.

$$
\begin{aligned}
& R 42=\frac{\operatorname{MIN}(0 ; 0 ; 0 ; 0 ; 2)}{0}=\frac{0}{0}=0 \\
& R 43=\frac{\operatorname{MIN}(0 ; 0 ; 0 ; 0 ; 2)}{0}=\frac{0}{0}=0
\end{aligned}
$$

Berikut ini adalah hasil matriks keputusan $\mathrm{R}$ yang terbentuk :

Matriks $\mathrm{R}=$

$$
\left(\begin{array}{llll}
0.898 & 0.934 & 0.935 & 0 \\
0.894 & 0.934 & 0.943 & 0 \\
0.974 & 0.973 & 0.947 & 0 \\
1.000 & 1.000 & 1.000 & 0 \\
0.981 & 0.942 & 0.912 & 0
\end{array}\right)
$$

Berdasarkan bobot yang sudah ada sebelumnya, maka langkah berikutnya adalah mengalikan bobot preferensi dengan nilai matriks keputusan ternormalisasi untuk mendapatkan alternatif yang dinyatakan lulus dalam penilaian

$$
V_{i}=\sum_{j=1}^{n} w_{j} r_{i j}
$$

Persamaan 3

evaluasi kompetensi dasar motivator (EKODAM). Langkah berikutnya adalah melakukan perhitungan nilai bobot preferensi untuk setiap alternatif menggunakan persamaan 3.

Keterangan : $\mathrm{Vi}=$ Rank untuk setiap alternatif

$$
\begin{aligned}
& \mathrm{wj}=\text { Nilai bobot untk setiap kriteria } \\
& \text { rij }=\text { Nilai rating kinerja ternormalisasi }
\end{aligned}
$$

\begin{tabular}{|c|c|c|c|c|c|c|c|}
\hline \multirow{2}{*}{\multicolumn{2}{|c|}{ KANDIDAT ALTERNATIF }} & \multicolumn{4}{|c|}{ KODE KRITERIA } & \multirow{3}{*}{$\begin{array}{l}\text { NILAI } \\
\text { BOBOT } \\
\text { PREFERENSI }\end{array}$} & \multirow[t]{3}{*}{ KETERANGAN } \\
\hline & & \multirow{2}{*}{$\begin{array}{l}\text { Kl } \\
\text { Tahap } \\
\text { Dasar }\end{array}$} & \multirow{2}{*}{$\begin{array}{l}\text { K2 } \\
\text { Tahap Menengah }\end{array}$} & \multirow{2}{*}{$\begin{array}{l}\text { K3 } \\
\text { Tahap } \\
\text { Lanjutan }\end{array}$} & \multirow{2}{*}{$\begin{array}{l}\text { K4 } \\
\text { Ketidakhadiran }\end{array}$} & & \\
\hline $\begin{array}{l}\text { Kode } \\
\text { Motivator }\end{array}$ & Nama Motivator & & & & & & \\
\hline M1 & Maulinda & 0.898 & 0.934 & 0.935 & 0 & 0.830 & Lulus \\
\hline M2 & Indah Muwartini & 0.894 & 0.934 & 0.943 & 0 & 0.831 & Lulus \\
\hline M3 & $\begin{array}{l}\text { Marita } \\
\text { Rachmawati }\end{array}$ & 0.974 & 0.973 & 0.947 & 0 & 0.868 & Lulus \\
\hline M4 & Neneng Marlina & 1.000 & 1.000 & 1.000 & 0 & 0.900 & Lulus \\
\hline M5 & Nani Subekti & 0.981 & 0.942 & 0.912 & 0 & 0.850 & Lulus \\
\hline \multicolumn{2}{|c|}{ Bobot Kriteria (dalam \%) } & 0.30 & 0.30 & 0.30 & 0.10 & & \\
\hline
\end{tabular}

Berikut ini adalah contoh perhitungan nilai bobot preferensi untuk setiap alternatif :

1. Alternatif motivator bernama "Maulinda" (M1).

$$
\begin{aligned}
& =\{(0.898 \times 0.3)+(0.934 \times 0.3)+(0.935 \times 0.3) \\
& =0.830
\end{aligned}
$$

2. Alternatif motivator bernama "Indah Suwartini" (M2).

$$
\begin{aligned}
& =\{(0.894 \times 0.3)+(0.934 \times 0.3)+(0.943 \times 0.3) \\
& =0.831
\end{aligned}
$$

Hasil akhir dari perhitungan nilai bobot prefensi setiap alternatif dapat dilihat pada tabel 8 .

Tabel 8. Hasil Perhitungan Nilai Bobot Preferensi Setiap Alternatif 


\subsection{Pemodelan Sistem Usulan}

Model fungsionalitas dari sistem penunjang keputusan perpanjangan kontrak kerja motivator pada Yayasan Pengembangan Anak Indonesia BIMBA AIUEO digambarkan menggunakan UML Use Case Diagram. Model tersebut dapat dilihat pada gambar 7 .
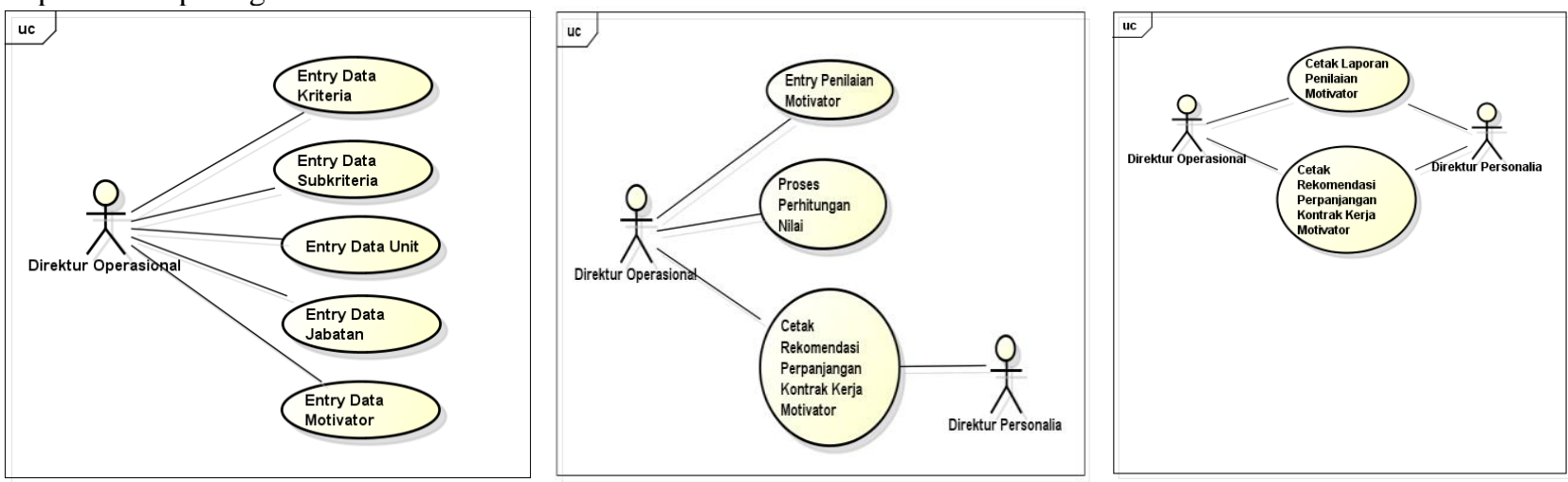

Gambar 7. Class Diagram

Gambar 7 merupakan model fungsionalitas sistem yang digunakan pada sistem perpanjangan kontrak kerja motivator yang terdiri atas: entry data kriteria, entry data sukriteria, entry data unit, entry data jabatan, entry data motivator, entry penilaian motivator, proses perhitungan nilai dan cetak rekomendasi perpanjangan kontrak kerja motivator, cetak laporan penilaian motivator dan cetak laporan rekomenasi perpanjangan kontrak kerja motivator.

\subsection{Perancangan Basis Data}

Gambar 8 merupakan model data konseptual menggunakan UML Class Diagram yang terdiri dari 9 (sembilan) kelas, yaitu : motivator, jabatan, unit, penilaian, kriteria, subkriteria, detilnilai, rekomendasi dan normalisasi. Kelas motivator digunakan untuk merekam informasi motivator, kelas jabatan digunakan untuk merekam informasi jabatan motivator, kelas unit digunakan untuk merekam informasi unit kerja, kelas penilaian digunakan untuk merekam informasi penilaian kerja motivator, kelas kriteria digunakan untuk merekam informasi kriteria penilaian dan bobotnya, kelas subkriteria digunakan untuk merekam informasi subkriteria penilaian, kelas detilnilai digunakan untuk merekam informasi detil penilaian, kelas rekomendasi digunakan untuk merekam informasi rekomendasi penilaian dan kelas normalisasi digunakan untuk merekam informasi nilai bobot ternormalisasi

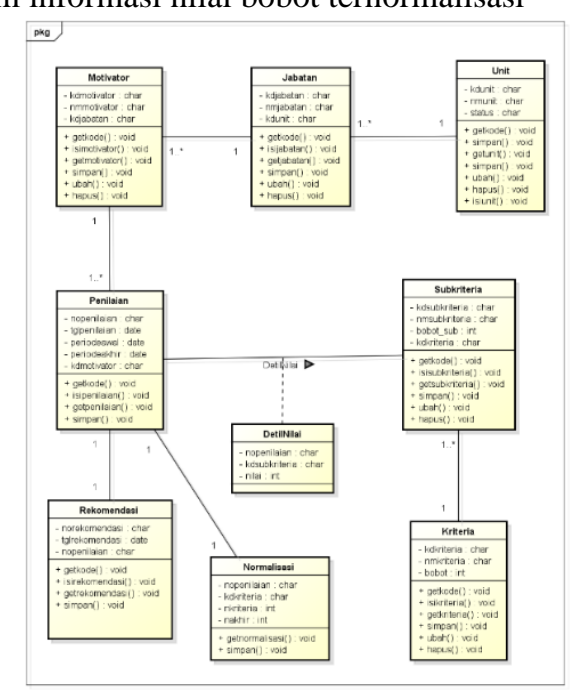

Gambar 8. Class Diagram

\subsection{Tampilan Menu}

Gambar 9 merupakan tampilan menu untuk sistem penunjang keputusan untuk menentukan perpanjangan kontrak kerja motivator pada Yayasan Pengembangan Anak Indonesia biMBA AIUEO terdiri atas 3 (tiga) tampilan menu, yaitu : menu file master, menu transaksi dan menu laporan. Menu file master terdiri dari menu yang digunakan untuk menginput : data kriteria, data subkriteria, data unit dan data motivator. Menu transaksi terdiri dari : entry penilaian motivator, proses perhitungan nilai dan cetak form 
rekomendasi perpanjangan kontrak kerja motivator. Sedangkan untuk menu laporan terdiri dari : cetak laporan penilaian motivator dan cetak laporan hasil rekomendasi perpanjangan kontrak kerja motivator.

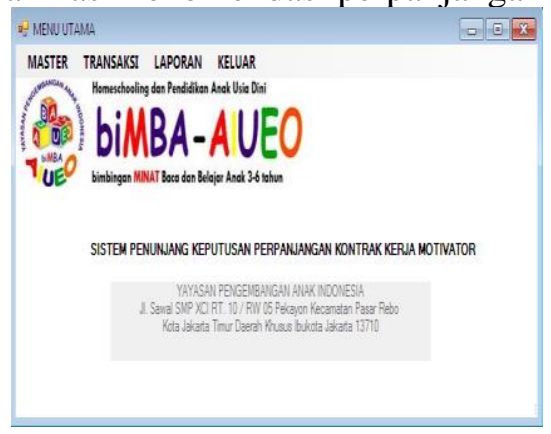

Gambar 9. Menu Utama

Gambar 10 merupakan form untuk menginput data penilaian terhadap motivator pada periode tertentu. Form entri penilaian terdapat inputan nomor penilaian, tanggal penilaian, periode penilaian, kode motivator, nama motivator, kriteria, subkriteria dan nilai setiap subkriteria.

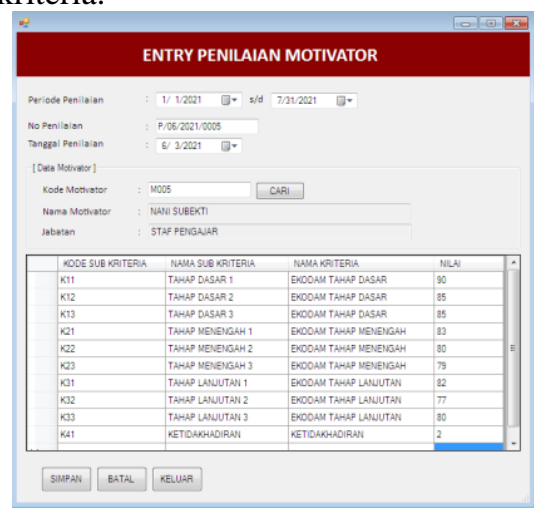

Gambar 10. Form Penilaian Motivator

Gambar 11 merupakan form untuk memilih motivator yang lulus dalam tes evaluasi kompentensi dasar motivator (EKODAM) dan akan diperpanjang kontrak kerjanya. Adapun persyaratan untuk dapat kontrak bagi motivator yang memenuhi syarat, yaitu minimal nilai akhir dari hasil evaluasi kompetensi dasar motivator (EKODAM) lebih besar atau sama dengan 80 .

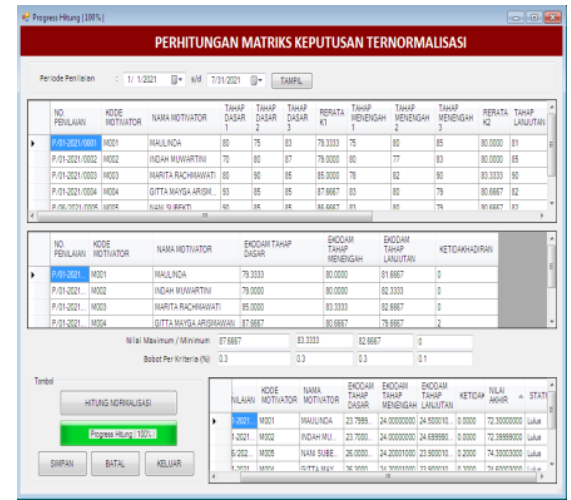

Gambar 11. Form Perhitungan Nilai

Gambar 12 merupakan contoh keluran rekomendasi perpanjangan kontak kerja motivator yang dikeluarkan oleh sistem. Keluaran informasi yang dihasilkan oleh aplikasi SPK tersebut bersifat rekomendasi untuk Ketua YPAI biMBA AIUEO, apakah akan memutuskan memperpanjang kontrak kerja atau tidak bagi motivator yang dinyatakan lulus dalam penilaian. 


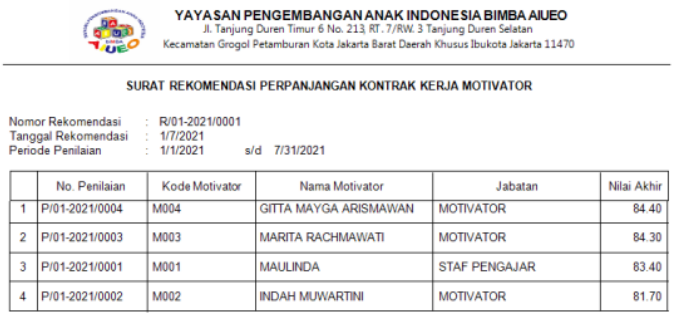

Jakarta, 06/03/2021
Direktur Operasional

Gambar 12. Hasil Keluaran Rekomendasi Perpanjangan Kontrak Kerja Motivator

\section{KESIMPULAN}

Berdasarkan hasil analisa masalah, perancangan dan implementasi sistem penunjang keputusan perpanjangan kontrak kerja motivator pada Yayasan Pengembangan Anak Indonesia biMBA AIUEO, maka penulis dapat mengambil beberapa kesimpulan berikut : penerapan metode Simple Additive Weighting (SAW) pada aplikasi proses perhitungan nilai motivator mempercepat dalam pengolahan data penilaian motivator sehingga hasilnya menjadi lebih terstandarisasi, dikarenakan sudah memiliki bobot penilaian. Selain itu, fitur- fitur bantuan yang tersedia, seperti : modul entry pembobotan kriteria, modul entry penilaian dan modul perhitungan nilai yang dapat membantu pihak manajemen untuk menentukan hasil akhir evaluasi kompetensi dasar motivator (EKODAM) setiap motivator, serta dengan adanya modul cetak rekomendasi perpanjangan kontrak kerja motivator, maka pihak manajemen dapat membantu memberikan rekomendasi untuk menentukan motivator yang akan diperpanjang kontrak kerjanya.

\section{Daftar Pustaka}

[1] Dewanto, Sistem Penunjang Keputusan Investasi Saham dengan Metode SAW di Bursa Efek Jakarta. Jakarta: Teknik Informatika Universitas Esa Unggul, 2015

[2] F. Frieyadie, "Penerapan Metode Simple Additive Weight (SAW) Dalam Sistem Pendukung Keputusan Promosi Kenaikan Jabatan," J. Pilar Nusa Mandiri, vol. 2(25), 2016

[3] S. and W. Primahudi, "Sistem Pendukung Keputusan Untuk Pemilihan Karyawan Dengan Metode Simple Additive Weighting di PT. Herba Penawar AlWahida Indonesia," JIMP - J. Inform. Merdeka Pasuruan, vol. 2(1), 2016.

[4] A. G. and et. al. Anto, "Sistem Pendukung Keputusan Penilaian Kinerja Karyawan Menggunakan Metode SAW," JUITA, vol. 3(4), 2015.

[5] A. U. Aini, Riadhotun Nurul and Hamdani, "Perancangan Model SPK Dalam Penilaian Guru Terbaik Menggunakan Metode Fuzzy dan SAW Studi Kasus : SDIT Yasir Cipondoh,” J. Idealis, vol. 2(2), 2019.

[6] S. Gunawan, "Sistem Pendukung Keputusan Pemilihan Guru Terbaik Pada SMA Negeri 2 Kutacane dengan menggunakan Metode Simple Additive Weighting (SAW)," J. Pelita Inform. Budi Darma, vol. 9(3), 2015.

[7] R. Setyani, R. E., \& Saputra, "Flood-prone Areas Mapping at Semarang City by Using Simple Additive Weighting Method," Procedia - Soc. Behav. Sci., vol. 227, no. 378-386, 2016.

[8] D. Sunyoto, Metodologi Penelitian Akuntansi. Bandung: PT. Refika Aditama, 2013.

[9] H. Asmoko, Teknik Ilustrasi Masalah-Fishbone Diagrams. Magelang: BPPK, 2013. 